\title{
Disclosure of Intellectual Capital by Digital Companies
}

\author{
Larisa Kokh \\ Department of International \\ Economic Relations \\ State Marine Technical \\ University Saint-Petersburg, \\ Russialkokh@mail.ru
}

\author{
Yuriiy Kokh \\ Department of Innovation \\ Economics \\ State Marine Technical University \\ Saint-Petersburg, Russia \\ y_kokh@mail.ru
}

\author{
Veronika Prosalova \\ Department of Management \\ and Economics \\ Vladivostok State University of \\ Economics and service. \\ Branch in Nachodka \\ Vladivostok,Russia \\ prosalova@mail.ru
}

\begin{abstract}
The main purpose of the article is to define the essence of intellectual capital as a multi-component factor, analyze the structure and methods of intellectual capital evaluation and assess the feasibility of disclosure of information on it to external users. On the basis of the concept of information and communication technologies application, a segment of digital economy enterprises is selected. 10 Top companies which have had the maximum market capitalization by the beginning of 2019 are presented. Seven out of the ten companies are digital companies which have appeared thanks to digital technologies. With the use of these companies as an example, availability of assets not disclosed in their financial statements, which have great impact on company's cost is shown. These assets make the intellectual capital. Development evolution of the "intellectual capital" definition essence starting from the mid-1990s is given in the article, when the boom of Internet companies was observed, till the present time, when scientific interest to this definition has occurred once again due to active transition of all the countries' economies to digital ones. Intellectual capital is an integral factor consisting of many heterogeneous components. The minimum quantity of components of intellectual capital is reflected in the Statement on Financial Position of the company as intangible assets. The largest part of intellectual capital is defined as hidden assets. They are not accessible for an investor, hard to identify and assess. However, they are the ones that make a substantial contribution to the company's cost. Existing by the present moment approaches to structuring intellectual capital is analyzed in the article, and an overview of the methods of intellectual capital evaluation is presented. Preference is given to non-financial methods whose application allows receiving more reliable estimate of the intellectual capital cost. With substantiation of the necessity of development of recommendations on disclosure of information on intellectual capital, attention is drawn to availability of interconnection between intellectual capital and corporate governance.
\end{abstract}

Keywords - intellectual capital, intellectual assets, intangible assets, human capital, structural capital, organizational capital, client's capital, intellectual capital cost, digital companies

\section{INTRODUCTION}

At the present stage of economy's development, it is more and more often called the digital one, however, everyone construes this term in his own way. R. Bukh and R. Heeks have given it a rather flexible definition, in which they have put the probable in future technological changes, namely: "digital economy is a part of the total production volume which was fully or mainly produced on the basis of digital technologies by the companies whose business model is based on digital products or services" [1]. We fully support such an approach to understanding the digital economy [2]. The information and communication technologies (ICT) are the ones that make the basis of digital economy, and the concept of ICT application [1,2] allows selecting the companies which form the segment of the state digital economy. If you get the answer "No" to the following question: "Can a company carry out its activity without ICT?", then the company relates to the segment of digital economy and it may be classified as a digital one.

On September 14, 1998, for the first time in the history of world economy, the Microsoft Company with the market cost of USD 261 bln. representing digital economy got the first place in the rating of market capitalization having sidelined General Electric, an equipment manufacturer with the market cost of USD $257 \mathrm{bln}$. In Table 1, rating of the most expensive 10 companies of the world is given, out of them only three represent traditional economy branches. The largest seven world companies are digital ones. They either directly service all the digital economy (and not only it) creating software, or render their services on ICT basis.

TABLE I. THE TOP 10 WORLD COMPANIES ON MARKET

\begin{tabular}{|c|l|c|c|c|l|}
\multicolumn{7}{c|}{ TABLE I. } \\
\hline Place & Name & $\begin{array}{c}\text { Market } \\
\text { capitalization, } \\
\text { bln. }\end{array}$ & $\begin{array}{c}\text { Balance } \\
\text { cost, bln. }\end{array}$ & Country & \multicolumn{1}{|c|}{ Branch } \\
\hline 1 & $\begin{array}{l}\text { Amazon } \\
\text { Inc. }\end{array}$ & $\$ 802.18$ & $\$ 162.65$ & USA & $\begin{array}{l}\text { Retail (goods sale } \\
\text { via Internet) }\end{array}$ \\
\hline 2 & Microsoft & $\$ 789.25$ & $\$ 258.86$ & USA & $\begin{array}{l}\text { Software } \\
\text { development }\end{array}$ \\
\hline 3 & $\begin{array}{l}\text { Alphabet } \\
\text { Inc. } \\
\text { Google) }\end{array}$ & $\$ 737.37$ & $\$ 245.35$ & USA & Internet \\
\hline 4 & Apple Inc. & $\$ 720.12$ & $\$ 373.72$ & USA & $\begin{array}{l}\text { Electronics, } \\
\text { information } \\
\text { technologies }\end{array}$ \\
\hline 5 & $\begin{array}{l}\text { Berkshire } \\
\text { Hathaway }\end{array}$ & $\$ 482.36$ & $\$ 707.79$ & USA & $\begin{array}{l}\text { Insurance, finance, } \\
\text { railway transport, } \\
\text { utility, production } \\
\text { of foods and non- } \\
\text { foods }\end{array}$ \\
\hline 6 & Facebook & $\$ 413.25$ & $\$ 97.33$ & USA & Internet \\
\hline 7 & Tencent & $\$ 400.90$ & $\$ 723.52$ & $\begin{array}{l}\text { Conglomerate } \\
\text { (social networks, } \\
\text { exchange with } \\
\text { instant messages, } \\
\text { mass media }, \\
\text { mobile games etc. }\end{array}$ \\
\hline
\end{tabular}




\begin{tabular}{|c|c|c|c|c|l|}
\hline Place & Name & $\begin{array}{c}\text { Market } \\
\text { capitalization, } \\
\text { bln. }\end{array}$ & $\begin{array}{c}\text { Balance } \\
\text { cost, bln. }\end{array}$ & Country & Branch \\
\hline 8 & Alibaba & $\$ 392.25$ & $\$ 917.94$ & China & Internet \\
\hline 9 & $\begin{array}{c}\text { Johnson \& } \\
\text { Johnson }\end{array}$ & $\$ 347.99$ & $\$ 152.95$ & USA & $\begin{array}{l}\text { Pharmaceutical } \\
\text { industry }\end{array}$ \\
\hline 10 & $\begin{array}{c}\text { JPMorgan } \\
\text { Chase }\end{array}$ & $\$ 332.24$ & $\$ 2,622.53$ & USA & Banking \\
\hline
\end{tabular}

One of the features of digital economy companies is change of the company's assets structure. For digital companies it is common that the company's intellectual assets prevail. One can understand how great digital companies' intellectual assets are by comparing their market cost and balance cost. The total assets of the Amazon company as per market cost exceed the total assets as per balance cost fivefold, the Microsoft company and Alphabet Inc., thrice, Apple Inc., twice, and Facebook, more than fourfold. This is the assessment of impact of the company's intellectual assets on its market cost. The intellectual assets are preferably called the company's intellectual capital.

Within the period from 2011 to 2012, the Organization of Economic Cooperation and Development conducted a research related to impact of intellectual capital on the company's growth and its innovative activity [3]. The research has shown that investments into intellectual capital contribute to the growth of labor productivity. Beside that, the direct relation between the quantity of patented inventions which are the component of intellectual capital and the volume of investments, namely, the enterprises in the USA and Sweden which actively patent their inventions attract fourfold investment if compared to similar companies in Italy and Spain.

The company's intellectual assets are intangible by their nature, and, consequently, do not have a definite form and the corresponding cost. They are featured as "hidden assets" because it is difficult to determine their contribution to the company and quantitatively assess them in financial statements $[4,5]$.

As they understand now, the company's intellectual capital includes software, patents, copyrights, client lists, licensees and franchises, import quotas, trademarks, relations with clients and vendors, client loyalty, market share and marketing rights. This list is not an exhaustive one. Intellectual capital also includes processes, technologies, experience of top-managers and average executives. Knowledge obtained and acquired by employees while they are working for the company is the special part in the intellectual capital. The notion "intellectual capital" is much wider than the notion "intangible assets" well known to all as one of the elements of the company's fixed assets. As per International Financial Reporting Standards (IAS) 38 "Intangible Assets", to relate an asset to a group of intangible assets and reflect it in the company's balance sheet, it is necessary that the intangible asset correspond to the criteria of identification, check of resources and availability of the future economic profits. Thus, any intangible asset which may be identified separately from other assets has a period of useful application of more than one year, it may bring economic profits to the company, checked and used by the company itself, and it is possible to authentically determine its primary cost, it is reflected in the company's balance sheet. Many specialists in the area of accounting state the idea of growth of value of intangible assets in the business of those enterprises for which knowledge and technologies play the leading part in the competitiveness and success of business, i.e. for the enterprises of digital economy, and recommend to pay special attention to IFRS (IAS) 38 "Intangible Assets". However, the analysis of intangible asset share in fixed assets of the digital economy companies (Table 2) has shown the value not exceeding 12\% for two companies and only once for the four-year period of observations. The minimum share of intangible assets is observed with the Apple Inc. company, in 2018, the intangible assets are not available in the company's balance sheet.

TABLE II. DYNAMICS OF THE COMPANIES' INTANGIBLE ASSETS OF DIGITAL ECONOMY

\begin{tabular}{|c|c|c|c|c|c|c|c|c|}
\hline \multirow{2}{*}{ Name } & \multicolumn{2}{|c|}{2015} & \multicolumn{2}{|c|}{2016} & \multicolumn{2}{|c|}{2017} & \multicolumn{2}{|c|}{2018} \\
\hline & $m \ln$ & $\%$ & $m \ln$ & $\%$ & $m l n$ & $\%$ & $m l n$ & $\%$ \\
\hline $\begin{array}{l}\text { Amazon } \\
\text { Inc. }\end{array}$ & $\$ 992$ & 3.4 & $\$ 854$ & 2.3 & $\$ 3,371$ & 4.7 & $\$ 4,110$ & 4.7 \\
\hline Microsoft & $\$ 4,835$ & 9.3 & $\$ 3,733$ & 6.9 & $\$ 10,106$ & 11.5 & $\$ 8,053$ & 9.0 \\
\hline $\begin{array}{l}\text { Alphabet } \\
\text { Inc. } \\
\text { (Google) }\end{array}$ & $\$ 3,847$ & 6.7 & $\$ 3,307$ & 5.3 & $\$ 2,692$ & 3.4 & $\$ 2,220$ & 2.3 \\
\hline Apple Inc. & $\$ 3,893$ & 1.9 & $\$ 3,206$ & 1.5 & $\$ 2,298$ & 0.9 & $\$ 0$ & 0 \\
\hline Facebook & $\$ 3,246$ & 11,7 & $\$ 2,535$ & 8.3 & $\$ 1,884$ & 5.2 & $\$ 1,294$ & 2.3 \\
\hline Twitter & $\$ 141.01$ & 6.8 & $\$ 95.33$ & 4.3 & $\$ 49.65$ & 2.4 & $\$ 45.02$ & 1.5 \\
\hline
\end{tabular}

Consequently, the Statement on Financial Position of the company does not provide assessment of the company's intellectual capital in full scope. For the companies of digital economy with a big share of intellectual capital, there are no statements which allow external analysts, including potential investors, to authentically assess the company's costs as the significant part of the market cost of the company, as the cost of its intellectual capital has remained off the official financial statements. It's not a secret that in the age of information technologies, by throwing in the "proper" news, most often fake one, one can achieve rise or fall of shares cost at the stock exchange. The information asymmetry reflecting the lack of information on the probable future events in the companies only deepen this problem.

The aim of our research work is to analyze the structure and methods of assessment of intellectual capital, and also evaluate the feasibility of disclosing information about it, having determined its essence.

\section{STRATEGY AND PROCEDURE OF THE RESEARCH}

During research, scientific published papers relating to the problems associated with intellectual capital were analyzed. The period of time starting from the 2 nd half of 1990s of the last century up till present has been selected. The 2nd half of 1990s features by rapid growth of Internet companies' shares cost. It was then that they started talking about intellectual capital of those companies, which, from the point of view of the investors, made a lion's share in the cost of dotcoms. The fall of dotcom market took place on 10 March 2000, when NASDAQ index, having reached its maximum, fell for more than one and a half times within a 
trade session. One of the causes is considered to be an unauthentic assessment of the cost of Internet companies' assets. The published papers of 2000s features by the depth of problems studied associated with intellectual capital. While continuing to specify the components of the "intellectual capital" integral factor, the authors propose the procedures of its assessment; try to determine the connection between intellectual capital and company's cost. In the latest scientific articles, questions are raised which are associated with disclosure of information on intellectual capital and its connection with corporate governance.

In the process of research, they used such scientific procedures as analysis, comparison, generalization and grouping.

\section{RESULTS}

Calculations on the leading digital economy companies showed a big gap between the market cost and balance cost of the companies that is logically explained by availability of shares with the companies of digital economy which are not reflected in financial statements, i.e. intellectual assets or intellectual capital. These assets are not only intangible, but are often non-monetary and do not implicitly belong to the companies. Due to this fact, only the insignificant part of intellectual assets is reflected in financial statements (less than $10 \%$ of capital assets), the remaining part is not disclosed anywhere.

Causes of impossibility of development of intellectual information disclosure unified standards are explained. At the same time, it is highlighted that positive experience of some countries in development of recommendations on disclosure of information in the statements regarding intellectual capital proves that to solve this problem is feasible. Attention has been drawn onto necessity of studying the interrelation between intellectual capital and corporate governance.

Analysis of the existing methods of assessment of intellectual capital allowed giving recommendations on preferable usage of non-financial procedures of evaluation, as financial procedures of evaluation often distort the real value. It has been marked that digital economy creates feasibilities to develop new procedures of assessment of intellectual capital on account of technologies of development of data large arrays on construction of complicated models allowing to more authentically measuring the cost of intellectual capital components.

\section{DISCUSSION}

Before we examine the issues of structuring of intellectual capital, we will give its more exact definition disclosing the essence of this definition. As it has been justly mentioned by B. Marr and J.Chatzkel, the authors of article [6], intellectual capital has interdisciplinary nature. People of different professions and different life experience understand the intellectual capital in different ways. Specialists in accounting are supported by International Standards of financial statements in their activities, where it is strictly fixed what exactly can be related to intangible assets. Specialists in the area of HR management of a company confine the notion "intellectual capital" up to the level of specific employees and personnel of the company as a whole, making emphasis on skills, knowledge and relations of employees. Marketing specialists' associate intellectual capital firstly with the company's brand, its trade mark and other attributes associated with the company's recognition. We will consider intellectual capital from the point of view of an investor; we are interested in that invisible in the company's balance sheet part of assets which substantially influences its cost.

From the mid-90s of the last century, a large quantity of works dedicated to the problems associated with understanding of the essence of intellectual capital, its measurement and influence on the company's cost were published.

Klein and Prusak defined intellectual capital as intellectual material which can be formalized, collected and used for production of an asset with higher cost [7] Edvinsson and Malone stated that intellectual capital meant knowledge which can be transformed into value [8]. Stuart stated that knowledge, information and experience as the constituents of intellectual capital are tools for making wealth [9]. Sullivan defined the essence of intellectual capital as knowledge that can be turned into profit [10]. Edvinsson, Malone and Kok considered intellectual capital as a break that can be observed between the balance cost and market cost of a company $[8,11]$. A group of authors from Greece (Dimitrios Maditinos, Dimitrios Chatzoudes, Charalampos Tsairidis, Georgios Theriou), while considering the problem of influence of intellectual capital on market cost and financial efficiency of the company, analyzed the positions of the scientists above regarding the essence of intellectual capital and came to the conclusion that the intellectual capital should be construed as the hidden cost which is not reflected in financial statements and leads the company to getting competitive advantages [12].

Discussion relating to the essence of intellectual capital continues, but one can already state that intellectual capital has its specific features which make it different from other kinds of company's asset, namely, firstly, while making contribution to improvement of the company's competitive positions and company's cost, intellectual capital components do not have material shape and have the attribute of intangibility. Secondly, the majority of the components of intellectual assets are of non-monetary nature. Thirdly, intellectual capital is unique in its nature, as a rule, it is difficult to copy it, and it cannot be changed by material or monetary assets. This gives a right and imposes necessity to consider it as an independent asset, structure it, evaluate or manage it.

Intellectual capital is an integrated factor including a large quantity of vastly varied components. All these components may be structured this or that way. While generalizing the research works of Edvinsson and Malone [8], Stewart [9], V.A. Suprun [13], M.K. Akhmyatov and his colleagues from the South Ural State University [14], one can structure intellectual capital in the following way.

The first group includes the components related to competences of the company's employees, the human capital, so to say. Knowledge, experience and skills available with or obtained by the employees cannot belong to the company as they belong to specific 
employees of the company only. The employees work for the company, they can leave it any time, taking with them their knowledge, experience and talents. This specific feature of the human capital does not allow regarding it as non-material assets and contributes to relation of the human capital to a separate group. One should pay attention to the fact that human capital is not only a total of knowledge, experience and talent of a specific employee. The collective work has its synergetic effect many times multiplying the efficiency of individual contribution of every participant to the total result.

The structural capital makes the second group, including the client's capital and organizational capital.

The organizational capital consists of the process and innovative capital. The process capital includes the aligned business processes, technologies, corporate culture, information and communication support. The innovative capital includes the cost expression of the total of innovative designs at the stage of development or making already the intellectual property, and also received copyrights, certificates and patents. Organizational capital mainly belongs to the company and can be the object of purchase and sale. To gain success in business, the company has to regularly reconsider its organizational capital toward its improvement. This means both investments into research activity and permanent development of corporate culture which is part of intellectual capital.

The client's (or consumer's) capital firstly includes the trademark, licensees, franchise, data base, and also relations with the clients and vendors. Thus, the company is the only holder of the client's capital. Sometimes, the client's capital is called the capital of relations, for a significant part in the company's successful activities is with contracts and agreements with partners, business reputation of the company, channels of product distribution and orders portfolio. A company with a good business reputation may sell products at higher prices, increase the volumes of sales, use high loyalty of the clients and employees involve the best specialists in labor. Often, trade marks and brands are the symbol of business reputation.

E. Brooking [15] proposed a slightly different structure of intellectual capital. He divided it into four groups as follows:

- Market assets, including trade mark, reputation, permanent clients and distribution channels;

- Human assets, including knowledge, professional skills, knowledge and skills associated with work, psychometric characteristics, motivation and stimuli, ability to train oneself;

- Intellectual property, including patents, copyright, certificates and trade mark;

- Infrastructure assets, including corporate culture, risk management system, information technologies and communication systems, business processes.

However, one should note that E. Brooking's structure is principally not different from the previously described one, for the same components are included both in the first and in the second structure of intellectual capital.
Some researchers cut short the set of intellectual capital components. Thus, Jason G. Cummins, while considering the approaches to evaluation of intangible assets [16] distinguishes only two kinds of intangible assets: intellectual property (patents, trade marks, brands, secret formulae etc.) and organizational capital (business models, design, processes and information technologies). Thus, Jason G. Cummins excludes client's and human capital from intellectual capital. Jason G. Cummins might be called a skeptic in relation to the significance of intellectual capital for a company. His research work proved that only information technologies were significant when assessing the impact of intellectual capital on the company's efficiency. Maria do Rosário Cabrita, Jorge Landeiro Vaz made the opposite conclusion based on their research work. While analyzing the intellectual capital of Portuguese banks, they proved that the components of intellectual capital interact, and thus, increase the company's efficiency [17]. Researches within the period from 2011 to 2012 made by the Organization of Cooperation and Development showed that in many countries, the coefficient of correlation between the market cost of the enterprise and investments into intellectual capital is positive and shows high level of interdependence of these two factors. At the same time, financial statements of the companies give limited information on this asset, and, as a consequence, this becomes obstacle for investments to and management of the enterprise [3].

The analysis conducted has shown the lack of single understanding of the essence and components of intellectual capital, for largely, the structure of intellectual capital depends on specifics of the company's functioning. This, in turn, does not allow developing uniform standards of disclosure of information on intellectual capital. However, there is already positive experience of existing recommendations on disclosure of information on intellectual capital in the statements and their applications in practice. Thus, within the period from 1997 to 2003, such recommendations were published by the Ministry of Trade and Industrial Development of Denmark ("the Danish Principles"), from 2002 to 2004, by the Ministry of Economics, Trade and Industry of Japan, in 2006, by the Federal Ministry of Economics and Technologies of Germany, in 2011, by the Ministry of Finance of France [3].

If there are no standards or recommendations on disclosure of information on intellectual capital, then, as a rule, the purpose of reports on intellectual capital is not to disclose information on the structure of the company's intellectual capital components, not to exactly determine the contribution of intangible assets into the company's cost, but in creation of favorable for investors impression on the company's growth potential. The report turns into a sort of PR-campaign increasing the company's rating and asymmetry of information in the market and disorienting the users. A vivid confirmation for this is the story with the Swedish insurance company Scandia: against the background of issuance of reports on intellectual capital in 1999-2000, there appeared a speculative demand for its shares, however, already in 2002 , they lost about $90 \%$ of market value, after that, the company stopped publishing 
reports [18]. Though in the company's annual report there is a section dedicated to the human capital, the most significant elements disappeared from it, for example, Scandia's Navigator. Many company's topmanagers view reports on intellectual capital as documents for internal usage and disclose information contained in them only in private conversations with potential investors. Only one third of companies in Great Britain which calculated the intellectual capital for investors disclosed it in financial statements. Dutch companies did the same [3].

However, the negative experience gained does not cancel the results of all research on the theory and practice of intellectual capital. Recently, more and more often there have been held discussions on inclusion of intellectual capital in the area of managerial interests, on interrelation of corporate governance and disclosure of information on intellectual capital [19]. This only proves that more serious approach is required to recommendations on disclosure of information on intellectual capital and methods of its assessment applied.

The most complete survey of existing approaches to assessment of intellectual capital is presented on the personal Karl-Erik Sveiby's website (http://www.sveiby.com). He grouped all the methods into 4 groups as follows:

- Direct Intellectual Capital Methods;

- Market Capitalization Methods;

- Return on Assets Methods;

- Scorecard Methods.

These methods are described in detail in the works of $\mathrm{K}$. Sveiby himself [20], and also in the articles of S.A. Samusenko [21], L.V. Postanogova [22], Yu. Dukhnich [23], P.V. Romanteev [24]. The first three methods are the methods of financial assessment; all of them appeared in the $90 \mathrm{~s}$ of the XX century. The most arguable and unauthentic are market capitalization methods. They are based on assessment of intellectual capital using comparison of the company's balance cost and market cost. All these methods are based on the theory of effective market, which, as the latest research works show, are far from real events occurred in the financial market [25]. Due to the same reason there are doubts of the results received during usage of methods based on ROA factor. A rather exact assessment can be received when using the intellectual capital direct measurement methods. However, not for all the components of intellectual capital there exists a formula or algorithm of calculation of its value. Besides, as K. Sveiby pointed out, the use of methods of financial assessment in intellectual capital management may lead to over evaluation of its cost at an attempt to develop on their basis the mechanisms of motivation of company's employees [20].

Firstly, the methods of non-financial measurements of intellectual capital include the System of Balanced Factors of R. Norton and D. Kaplan who modified the basic model of the System for assessment of intellectual capital having preserved the traditional four projections: finance, clients, business processes and training and development. A vivid representative of the group of non-financial measurements is Scandia Navigator proposed by Edvinssion and Malone, which draws attention to five aspects of the company's activity. The first aspect is financial estimated on the basis of the company's financial statements. The second aspect is associated with the assessment of client's base. The third aspect is related to the company's business processes. The fourth aspect includes innovative activities of the company which gives confidence in successful functioning of the company in future. The fifth aspect is human capital.

\section{CONCLUSIONS}

Thus, the digital economy based on information and communication technologies has given rise to a new type of enterprises, namely, digital companies. We propose to refer a company fully to the digital segment of economy by means of ICT application concept.

A break between the market cost and balance cost of digital companies shows presence of hidden assets in large scope, which are identified as intellectual capital. However, as calculations proved, the specific weight of intellectual capital presented in the company's balance as intangible assets makes from $11 \%$ to $1 \%$ in long-term assets, and less than $1 \%$ in total assets. Thus, the main share of intellectual capital remained out of the framework of financial statements. Thus, one should develop new forms of statements which would disclose the structure of the company's intellectual capital and its cost estimate to external users.

The nature of intellectual capital itself, the complexity of its assessment has given rise to a large quantity of intellectual capital assessment methods. By $2010 \mathrm{~K}$. Sveiby distinguished 40 methods, at that; about 10 of them appeared after 2005. Digital economy gives new opportunities. One can increase authenticity of assessment of intellectual assets by means of accumulating data arrays on them, using methods of analysis of large data arrays, making more complicated the algorithms of calculation of the value of some components. Further, on their basis, one can search for answers to the questions whether the intellectual capital and its components have influence on the company's cost or its efficiency, for which companies this influence is substantial, how to learn to effectively manage the intellectual capital from the position of company's value growth.

While coming back to the problem of interrelation of intellectual capital and corporate governance, one can see that the issues of influence of the system of corporate governance on disclosure of information on intellectual assets are open, there is no system analysis of factors having influence on disclosure of information related to intellectual capital, and also how the Board of Directors and its structure influence the mechanisms of voluntary disclosure of information on the company's intellectual capital. All that can become a subject of consequent research works, for though research works in these directions have been conducted earlier, the results available partly contradict each other.

\section{REFERENCES}

[1] R. Bukh and R. Heeks, "Defining, Conceptualizing and Measuring the Digital Economy," Global Development Institute working papers, No. 68, 2017, available at: https://diodeweb.files.wordpress.com/2017/08/diwkppr68-diode.pdf 
(Accessed 28 June 2019).

[2] L. Kokh and Yu. Kokh, "Features of digital and digitalized economy," Digital Transformation of Economy and Industry. Works of the X research-to-practice conference with foreign participation. June 20-22, 2019

[3] Supporting Investment in Knowledge Capital, Growth and Innovation. Available at: http://www.oecdru.org/zip/9213028e5.pdf. (Accessed 28 June 2019).

[4] L. Edvinsson, "Developing intellectual capital at Skandia," Long Range Planning, vol. 30(3), 1997, pp. 366-373.

[5] R. Fincham and R. Roslender, "Intellectual capital accounting as management fashion: a review and critique," European Accounting Review, vol. 12(4), 2003, pp. 781-795.

[6] B. Marr and J. Chatzkel, "Intellectual capital at the crossroads: managing, measuring, and reporting of IC," Journal of Intellectual Capital, vol. 5(2), 2004, pp. 224-229.

[7] D.A. Klein and L. Prusak, "Characterizing Intellectual Capital," Ernst \& Young, Cambridge, 1994.

[8] L. Edvinsson and M.S. Malone, "Intellectual Capital: Realizing Your Company's True Value by Finding Its Hidden Brainpower," New York: Harper Business, 1997.

[9] T. Stewart, "The New Wealth of Organizations," New York: Doubleday, 1997.

[10] P.H. Sullivan, "Value-driven Intellectual Capital: How to Convert Intangible Corporate Assets into Market Value," Toronto: John Wiley \& Sons, 2000

[11] Kokh, "Intellectual capital management as part of knowledge management initiatives at institutions of higher learning," The Electronic Journal of Knowledge Management, vol. 5(2), 2007, pp. 181-192.

[12] D. Maditinos, D. Chatzoudes, C. Tsairidis, and G. Theriou, "The impact of intellectual capital on firms' market value and financial performance," Journal of Intellectual Capital, vol. 12(1), 2011, pp.132-151.

[13] V.A. Suprun, "Intellectual capital: The main factor in the competitiveness of the economy," Moscow: Komkniga, 2006, p. 192.

[14] M.K. Akhtaymov, E.A. Gonchar, and N.V. Tikhonova, "Evaluation of the intellectual capital of an organization as an element of the intrinsic value of an enterprise," Creative Economy, vol. 10 (8), 2016, pp. 945-960.

[15] Brooking, "Intellectual capital," International Thomson Business Press, 1996, p. 204.

[16] Jason G. Cummins, "A New Approach to the Valuation of Intangible Capital," NBER Working Papers 9924, National Bureau of Economic Research, Inc., 2003 ,

available at: https://ideas.repec.org/p/nbr/nberwo/9924.html (Accessed 28 June 2019).

[17] Maria do Rosário Cabrita and Jorge Landeiro Vaz. Intellectual Capital and Value Creation: Evidence from the Portuguese Banking Industry. Electronic Journal of Knowledge Management, vol. 4 (1), 2005, pp. 11-20.

[18] Karl-Erik Sveiby, "Methods for Measuring Intangible Assets," available at: http://www.sveiby.com/articles/IntangibleMethods.htm. (Accessed 28 June 2019)

[19] Ruth L. Hidalgo, Emma Garcia-Meca, and Isabel Martinez, "Corporate Governance and Intellectual Capital Disclosure," Journal of Business Ethics, 2011, pp. 483-495.

[20] Karl-Erik Sveiby, "Measuring Intangibles: Suggested Indicators with cases from professional service organizations and high tech firms," available at: https://www.researchgate.net/publication/327829240/ (Accessed 28 June 2019).

[21] S. A. Samusenko, "Intellectual capital as an object of accounting: new aspects," International Accounting, No 42(336), 2014, pp. 23 35 .

[22] L. V. Postanogova, "Qualitative models for evaluating the intellectual capital of a company," Modern scientific research and innovation, 2011, No 2, available at: http://web.snauka.ru/issues/2011/06/692 (Accessed 28 June 2019).

[23] Yu. Dukhnich, Intellectual capital: components, management, evaluation, available at: pit al.shtml (Accessed 28 June 2019).

[24] P. V. Romanteev, "Analytical review of intellectual capital appraisal methods," Economy, entrepreneurship and law, 2011, vol. 3(3). pp. 36-48, available at http://epp.enjournal.net/article/282/ (Accessed 28 June 2019).

[25] S. V. Cheremushkin, "The speculative component of the market value of companies in the context of the Minsky theory of financial instability: evidence against the efficient market hypothesis," Corporate Finance Management, No. 1, 2013, pp. 22-48. 